\title{
Article
}

\section{Recourse to Mediation in Times of Crisis}

\author{
Is Business Ripe for a New Approach That Saves Time and Preserves Relationships, Also in the \\ Field of Competition Law?
}

Pierre Kirch*

\section{Introduction}

The purpose of this article is to share some practical reflections on cross-border mediation and its application to Private Competition Disputes in Europe, at this time of crisis. The outbreak of the COVID-19 pandemic has led to a rethinking of methods of dispute resolution, everywhere. In Europe, whether before the European Union courts in Luxembourg or the civil and commercial courts in the Member States, judicial procedures are at a standstill at the time of writing (mid-2020). Once the courts get going again, it will probably take years to get the judicial system back in good working order. It may be necessary to take shortcuts to get the system back in shape, such as cancellation of hearings, recourse to summary forms of justice, etc. That is not what the parties bargained for at the outset of their judicial procedure.

Throughout the business world, it is possible to foresee, for all that has happened economically since lockdowns began in Europe - Italy in February 2020 and other European countries in March 2020 - an unprecedented number of disputes, many of which will turn upon con-

Avocat à la Cour (Paris \& Brussels Bars), Partner, Paul Hastings (Europe) LLP, mediator certified by the Centre de Médiation et d'Arbitrage de Paris (CMAP, Paris) and the Center for Effective Dispute Resolution (CEDR, London). This second contribution follows up on a related first contribution: Kirch P. (2019). Rereading Fisher \& Ury: Identifying the Advantages of Mediation in the Specific Setting of a Competition Law Dispute. Corporate Mediation Journal, 3(1-2), 22-25, doi: 10.5553/CMJ/254246022019003102007. tractual issues, and, indeed, a specific legal concept, that of force majeure in the case of a pandemic. In the judicial system, these conflicts will last for years, unresolved, and a vast body of case law will be created on this subject, where there was none before. Is there another way? Do companies truly find advantage in spending years in litigation in clogged and overwhelmed courts about force majeure issues (a fascinating issue for lawyers), when it is possible to change course, understand that the time of the courts is not the time of business, particularly in the emerging age of the digital economy, and go directly to the heart of their respective interests? The idea is to invite companies to put the pandemic behind them. To paraphrase a fundamental principle of Fisher \& Ury: 'look forward, not back' ('You will satisfy your interests better if you talk about where you would like to go rather than about where you come from'1).

There is one way to get into the time rhythms of business and not the courts, and that is through mediation. In the face of a crisis, through recourse to the mediation alternative, the parties are saying, 'Let's get through this together. Let's communicate. We can work this out together and survive.' The author of these lines is a competition lawyer who tends to see dispute resolution through the prism of competition-related disputes. In competition disputes, this way of thought is innovative. And yet, it corresponds to business logic, in that it constitutes a way to attempt to allow a business relationship to survive despite the dispute. This consideration

1. Fisher R. \& Ury W. (2011). Getting to Yes: Negotiating Agreement without Giving In (Revised 3rd ed.). By Fisher, Ury \& Bruce Patton. London: Penguins Books, p. 54. 
applies to all business disputes, regardless of whether they involve a competition element.

The Paris Bar Council is one of the first to have understood the full potential of mediation in times of crisis. On 28 April 2020, it announced the creation of an emergency mediation group for business disputes, in order to provide a structure by which companies could put together, with the help of an avocat médiateur, through videoconference meetings, rapid solutions to difficulties deriving from the crisis. And this at a time of total judicial standstill. It may be expected that other for a will follow suit in the post-pandemic world.

In many countries, including most countries in Europe, judicial systems, as they come out of lockdown, will be engulfed in unprecedented bottlenecks. The buzzword of deconfinement has become 'The world that we go back to will not operate as it did before.' This is true dispute resolution. There will be new approaches, which lead to a rethinking of how mediation can be useful in areas in which it has not made inroads in the past, including disputes grounded in competition lam principles, that is to say the functioning of markets, of supply and demand.

In this article, we will pay particular attention to how this applies to competition law. Competition law ('antitrust') is about everything that undertakings ('enterprises') do in markets, and to the extent that this is true, it can be said that the scope of competition law is as broad as economic activity in all of its facets. Given the unlimited ways that undertakings can interact in markets, through the supply and demand of goods and services, conflicts inevitably arise. This is part of the 'give and take' of doing business. These competition conflicts are resolved in various ways, principally by way of complaints to competition authorities, such as the European Commission [or national competition authorities: Competition and Markets Authority (CMA) (UK), Bundeskartellamt (Germany), Autorité de la Concurrence (France), etc.] or, more and more frequently, by way of what are called generically 'private enforcement' actions before the courts or an arbitral tribunal.

In recent years, private enforcement actions for infringement of competition law provisions have received considerable attention in Europe, and this for two reasons. First, the mainstream emergence of competition law regimes on a broad scale throughout the world, including Europe, as a virtual corollary of economic development. In 2000, there were only around 40 jurisdictions which had competition law regimes in place, on a worldwide basis. ${ }^{2}$ In 2020, more than 120 countries now have a form of laws in connection with the regulation of markets and the undertakings which operate in them and with protection against anticompetitive behaviour. This includes all Member States

2. Cf. 'Unveiling the World of Antitrust', Columbia Law School, 2014 Retrieved from www.law.columbia.edu/media_inquiries/news_events/ 2014/march2014/bradford-antitrust-project (consulted on 21 May 2020), which cites, in 2014, more than 120 jurisdictions having competition laws, following the 'rapid dissemination of competition laws' since the turn of the century (up from less than 40 in 1998). of the European Union, with advanced, sophisticated laws. In the European Union, specific legislation has been introduced to favour private enforcement actions in connection with competition law infringements.

The centrepiece EU provisions are set out in Directive 2014/104/EU of 26 November 2014 on 'certain rules governing actions for damages under national law for infringements of the competition law provisions of the Member States and of the European Union'3 (the Private Enforcement Directive). The deadline for implementation of the Private Enforcement Directive in the national law of the EU Member States was set at 27 December 2016. ${ }^{4}$ At the time of writing in mid-2020, we now have several years of experience with private enforcement cases before EU Member State courts arising out of implementation of the Private Enforcement Directive into national law. Indeed, in recent times, intense scrutiny has been directed by competition regulators and practitioners to the practical effects of the Private Enforcement Directive, and, in particular, to the potential for an increase in the volume of private damages actions that it has fostered in enforcement of the competition rules before the courts.

And yet, the Private Enforcement Directive includes provisions that are manifestly intended to take into account, at least indirectly, not only private enforcement via court action but also via 'consensual settlements'. Indeed, although the working hypothesis of the directive is private enforcement of the competition rules through damages claims before national courts, the possibility that parties may engage in consensual dispute resolution, such as would be the case through recourse to mediation, after such court claim has been brought, is contemplated and regulated by the Private Enforcement Directive, in its Chapter VI, entitled, effectively, 'Consensual Dispute Resolution'. This chapter involves a limited number of issues by which the recourse to, inter alia, mediation ('consensual dispute resolution') can have an effect on existing court procedures, such as suspension in the application of the limitation period and the effects of any consensual settlement on other court actions. A key point: the validation of recourse to various forms of consensual settlement, such as mediation, is enshrined in the text. Thus, this type of consideration as stated in the recitals of the Private Enforcement Directive:

To encourage consensual settlements, an infringer that pays damages through consensual dispute resolution should not be placed in a worse position vis-àvis its co-infringers than it would otherwise be without the consensual settlement. ${ }^{5}$

The key point is that the Private Enforcement Directive seems to encourage consensual dispute resolution such as mediation, but mithout regulating it directly and separately from cases brought before the courts. The Private Enforce-

Official Journal of the European Union, n L 349/1, 5 December 2014. Private Enforcement Directive, Art. 21(1).

Id, Recital 51 and Arts. 18-19. 
ment Directive represents just the beginning of the story. The European Commission has the legal obligation to review its effective implementation and effects and submit a report thereon at the 4-year mark of its implementation, by 27 December $2020 .^{6}$

As for mediation as a means of consensual dispute resolution, there exists, of course, a common EU legislative framework through the provisions of Directive 2008/52 EC of 21 May 2008 'on certain aspects of mediation in civil and commercial matters' ${ }^{7}$ (the Mediation Directive). Starting from the fundamental provisions of this directive as a conceptual framework, the EU Member States currently regulate mediation to varying levels of detail. The Mediation Directive itself is based on a standard, general definition of the concept of mediation:

Mediation means a structured process, however named and referred to, whereby two or more parties to a dispute attempt by themselves, on a voluntary basis, to reach an agreement on the settlement of their dispute with the assistance of a mediator. This process may be initiated by the parties or suggested or ordered by a court or prescribed by the law of a Member State. ${ }^{8}$

But the key point is to be found in the objective of the Mediation Directive as stated in its Article 1:

The objective of this Directive is to facilitate access to alternative dispute resolution and to promote the amiable settlement of disputes by encouraging the use of mediation and by ensuring a balanced relationship between mediation and judicial proceedings.

This said, the Mediation Directive is an instrument of EU law harmonisation, and its scope is limited to civil and commercial matters in cross-border disputes, provided that the dispute concerns rights and obligations which are 'at the parties' disposal under relevant applicable law'. ${ }^{9}$ In fact, from a business point of view, the remit is quite broad. It manifestly includes those crossborder commercial disputes which concern competition law matters.

And thus, European Union law favours and encourages, separately, both (i) mediation, as an alternative means of resolution of cross-border civil and commercial disputes, and (ii) private enforcement of the competition rules, including through 'consensual means'. What happens then, in practical terms, when these two elements are brought together, so that certain types of private competition disputes would be effectively and definitively resolved not through the enforcement action of competition authorities (following a complaint) nor through court or arbitral proceedings, but through mediation? That is the object of these reflections.

Id, Art. 1, 'Objective and Scope'.
Our reflections are subject to two qualifiers. The first is that the author is an antitrust practitioner in private practice: the scope of his reflections is limited to the nature of his practice, that is to say a practice of advice and assistance to undertakings, which enter into conflict with other undertakings with regard to matters involving competition, and the resolution of such conflict. Thus, these reflections do not encompass other, distinct areas of potential combinations of mediation and competition law, such as, in particular, the possibility for competition authorities to have recourse to mediation in the public enforcement of the competition rules. ${ }^{10}$ The second is that the author's approach to mediation is necessarily shaped by his own experience, in terms of concepts and methods and thus inevitably, in the instant case, by the conceptual and methodological framework of the mediation institutions to which he belongs through training and certification, which are the Centre de Médiation et d'Arbitrage de Paris (CMAP, Paris) and the Centre for Effective Dispute Resolution (CEDR, London). This point is important, given the broadness and variety of approaches to mediation, not only throughout the world, but also throughout Europe and even individual EU Member States such as France. $^{11}$

\section{Typology of Competition Disputes Which Could Be Usefully Submitted to Mediation}

As already noted, competition law is as broad as economic activity itself: where undertakings are present in the supply of goods and services to customers, competition rules may apply in various ways. EU law provisions on competition offer a useful guide to how this takes place in the most general conceptual terms, through what are known, in EU competition law circles, as the three 'pillars'.

The first pillar involves the behaviour of undertakings in markets, either (i) in tandem with other undertakings through a common will to act in a way which restricts or distorts competition or (ii) by acting unilaterally, but only to the extent that the undertaking concerned has considerable market power ('dominance') and is thus able, alone, to impose on other market players, suppliers or customers, restrictions on competition.

Thus, Article 101(1) of the Treaty on the Functioning of the European Union (TFEU) prohibits, in principle,

10. Cf. Zimmer D. \& Hoft J.C. (2013). Alternative Dispute Resolution in Antitrust Cases? On the Role of Mediation in US Antitrust and EU and German Competition Law. European Competition Law Review (ECLR), 434-442.

11. Cf. European Parliament (2014). Rebooting the Mediation Directive: Assessing the Limited Impact of its Implementation and Proposing Measures to Increase the Number of Mediations in the EU, PE 493.042 (EW). Retrieved from www.europarl.europa.eu/studies. 
covenants and concerted practices (collusion) by two or more undertakings, which may affect trade between the Members States and which have as their object or effect to restrict competition. Any agreements or concerted practices which fall within the prohibition are automatically null and void, unless subject to exemption. Indeed, Article 101(3) TFEU provides that agreements which restrict competition, on the one hand, but which represent economic benefits on the other, are to be exempted from the Article 101(1) TFEU prohibition, where four cumulative conditions under Article 101(3) TFEU are met, and, notably, that economic benefits derive directly from the restrictive covenant or practice: (i) contributions to improvement of production or distribution of goods or services, through the promotion of technical or economic progress; (ii) allowance for customers to gain a fair share of the resulting benefit; (iii) absence of any unnecessary restrictions, which do not contribute to the economic benefit; (iv) maintenance, despite the restrictions, of sufficient competition in respect of a substantial part of the products or services in question.

Here is a practical example of how such exemption may play out: the competition questions concerning exclusive territorial protection given by a brand owner to an exclusive dealer as enforceable against other dealers of the same brand, in other territories. The restriction of exclusivity may be commercially necessary in order to persuade a protected dealer to make investments in the development of sales in the protected territory. If other dealers could 'piggyback' on the investment, such dealer might be unwilling to make it. The economic benefit results from the fact that such protected investment may increase competition between different brands or result in other economic benefits. In such a context, private disputes may arise, for instance, over questions of whether such a restrictive covenant or practice of exclusivity between two or more undertakings qualifies for an exemption. Under EU law, there is no administrative procedure, which allows for companies to apply for some kind of certification that they qualify for an Article 101(3) TFEU exemption. Companies must 'self-assess' their situation with regard to whether agreements and practices are covered by an Article 101(3) TFEU exemption. This question of exemption can give rise to disputes between companies when difficulties arise in performance of contracts, in particular. This can block the pursuit of a commercial relationship. And in times of pandemic crisis and beyond, the blockage can last a long time if the parties seek resolution through oversubscribed courts or arbitration institutions. That is one of the reasons for which it can be posited that mediation may emerge as a new method to resolve these disputes.

As for potentially illegal unilateral market behaviour, the fundamental provision is set out in Article 102 TFEU, which prohibits the exploitation by one or more undertakings of a dominant market position insofar as it may affect trade between Member States. In recent years, the European Commission has tended to focus its sights for such abuse on undertakings whose dominant market positions derive from technological advances
(Microsoft, Google, Facebook, Amazon, etc.). The key point in application of Article 102 TFEU is that behaviour which may be perfectly legitimate for undertakings in normal situations may be illegal and thus prohibited for undertakings enjoying a dominant market position. The types of abuse possible are without limit. As a fundamental principle, it is considered that an undertaking in a dominant market position has a 'special responsibility' not to commit acts outside of the normal, neutral flow of business, that is to say to abstain from specific acts which could further reinforce dominance or procure gains deriving from dominance. Once again, potential private disputes between actors of abuse and their victims are boundless.

The second pillar involves merger control in all of its various forms, that is to say transactions where there is a change of control of a target undertaking and thus the 'concentration' of previously independent undertakings. This is M\&A, the change in control of undertakings. The concept of 'merger' includes the creation or change of situations of joint control of undertakings through joint ventures. The European Commission has jurisdiction to control the 'big ticket' mergers which meet the EU jurisdictional thresholds, as set out in Article 1 of the basic text, the EU Merger Control Regulation $n$ ${ }^{\circ} 139 / 2004$ on the control of concentrations between undertakings. ${ }^{12}$ Because the EU thresholds are high, the European Commission currently has jurisdiction over about 350 mergers per year (out of the many thousands, which take place between companies doing business in the EU). Since the introduction of EU merger control rules in 1989, some $9500 \mathrm{EU}$ merger control procedures have taken place before the European Commission in Brussels.

The third (and final) pillar involves the complex web of EU State aid rules, whose fundamental principles are set out in Articles 107-109 TFEU.

Of the three pillars, private enforcement disputes between undertakings, which could lead to resolution via mediation, would normally be limited to the behavioural realm of the first pillar under Articles 101-102 TFEU (restrictive covenants or concerted practices between undertakings, abuse of dominant position). Although private disputes can stem from the application of the rules on merger control and State aid, as referred to above, these cases would be somewhat rare candidates for mediation, whereas Articles 101-102 TFEU reflect the standard business dealings which can give rise to mainstream disputes and private enforcement actions and their potential resolution through mediation, with all of the advantages that such mediation can procure.

12. Regulation (EC) $n^{\circ} 139 / 2004$ of 20 January 2004 on the control of concentrations between undertakings, Official Journal of the European Union, $\mathrm{n}^{\circ} \mathrm{L} 24 /$ I of 29 January 2004. 


\section{Untapped Potential of Recourse to Mediation in Competition-Related Disputes}

Although, for practical reasons, we limit our reflections on recourse to mediation in a private competition dispute situation to the behavioural realm of Articles 101-102 TFEU, the scope thereof is somewhat boundless in practice. It is obvious that not all competitionrelated disputes could be subject to mediation, but a good number could be, if business were willing.

For instance, an undertaking that believes that it the victim of a cartel would probably be best served by filing a complaint with a competition authority which could investigate the matter and gather proof of the infringement rather than simply suing the alleged cartel participants and then attempting to draw the matter into mediation for a solution: the victim would have no conclusive evidence of the cartel, just suspicions, and thus no leverage in court or in mediation.

On the other hand, mediation in the cases contemplated by the above-discussed EU Private Enforcement Directive of 2014 seems eminently possible for mediation as a method, regardless of whether an action for damages has first been brought before the courts by the victim. This is because the directive relates, in substance, to damages actions which would be brought after a finding of infringement of competition law by a final decision of a national competition authority or by a court. Proof of the infringement has already been established in a decision of the competition authority concerned, and need not be proved again by the private claimant (thus, such private action is called a 'follow-on' claim). The purpose of the Private Enforcement Directive, then, is to enable the claimant to act without having to prove the reality of the infringement. The claim is limited to a demonstration of the quantum of the damage and the causal link. Article 9(1) of the directive states:

Members States shall ensure that an infringement of competition law found by a final decision of a national competition authority or by a review court is deemed to be irrefutably established for the purposes of an action for damages (...).

And we have already noted the indirect references given to mediation ('consensual dispute resolution') in Article 18 of the directive through, for instance, provisions related to suspension of court proceedings in damages cases where 'the parties thereto are involved in consensual dispute resolution concerning the claim covered by that action for damages'. In the event of a pre-existing commercial relationship between the parties, mediation would allow for them to take into account all of their business interests (and not just those deriving from the cartel infraction).
Indeed, in a more expansive vein, there are no obstacles to the submission to mediation of purely contractual disputes between the parties concerning the validity or not of restrictive covenants, without any preliminary determinations by a competition authority or the courts. This approach involves private enforcement in its purest form, since only the parties are involved and full and strict confidentiality is maintained. The objective of private enforcement in this instance is radically different from that of public enforcement by a competition authority, where deterrence is the goal, through the imposition of fines and publicity of the public enforcement action. In classical industrial terms, the scope of contractual disputes concerned would cover distribution and franchising agreements, patent rights and IP disputes, specialisation and R\&D agreements, contractual joint ventures, etc. The dispute would often hinge on whether a covenant was indeed restrictive, within the meaning of Article 101(1) TFEU, and if it were restrictive, whether it would qualify for an antitrust exemption within the meaning of Article 101(3) TFEU. That is, of course, the legal issue in dispute. Through recourse to mediation, the parties could be led to abandon their reasoning based on legal positions and to look for common ground solutions involving the attainment of business interests. At least that is the goal in the CMAP and CEDR style mediations as referenced above. But that is not all. The application of competition law follows rigorously the technology of the times, and in this respect it has been significantly affected, if not shaken, by the emergence of the digital economy in recent years. Hence the issue of the place of mediation in disputes involving competition disputes in high-tech business environments generated by the digital economy.

\section{Will the Emergence of the Digital Economy and Its Complexity Point to a New Reliance on Consensual Dispute Resolution in a Competition Framework?}

The emergence of the digital economy and its complexity (for instance, increasing reliance on artificial intelligence systems driven by the combination Big Data/ algorithms) could provide ground for new thinking about the scope of competition disputes. And, in turn, the emergence of a new kind of high-tech dispute could fall within the typology of cases for which mediation could be contemplated as an alternative means of dispute resolution. This is a speculative subject, and very complex. The truth is that, in Europe at least, under the pressure of globalisation, digital transformation ('digitisation') and the emergence of artificial intelligence, the relevance of the historical competition 
approach is being challenged, not only by iconoclast lawyers and economists, but, most recently, by enforcement authorities themselves.

In November 2019, the French and German competition authorities (Autorité de la Concurrence, Bundeskartellamt) published, on their respective websites, a joint 18-month study entitled 'Algorithms and Competition'. ${ }^{13}$ Several months earlier, the European Commission had published a commissioned study by an international panel of academics entitled 'Competition Policy for the Digital Era' (the 'Cremer Report'). ${ }^{14}$ On 9 December 2019, Margrethe Vestager, the European Commission Executive Vice President in charge of both the competition and the digital portfolios in the college of commissioners which entered into office on 2 December 2019, in a speech delivered in Brussels to an association of competition law experts, noted the

importance of checking whether our way of enforcing the rules is still right for this new world. The challenges we're facing, at the start of this new decade, mean that we need to look again at the tools we use to enforce the competition rules (...). The growing case of global trade, together with the power of digitization, can make it easier for customers to benefit from truly global markets. ${ }^{15}$

This new context could lead to radical change in the tools used to apprehend competition, in the coming months and years. The day after Mrs. Vestager's speech, on 10 December 2019, Charles River Associates, a worldwide competition economics consultancy firm, hosted a conference in Brussels, entitled 'Antitrust in Times of Upheaval: A Global Conversation'. Amongst the subjects: 'Do Regulators understand what's going on in Tech?' 'Are Privacy and Competition Finally Converging?"16 Coming back to Mrs. Vestager, she added this statement in her speech on 9 December 2019:

Business these days is increasingly global. That means huge new opportunities for European companies - but it also means they have a lot more at stake. And globalization can offer a better deal for consumers - but only if competition keeps working the way it should. Meanwhile, digitization is also creating new opportunities. New companies, with millions or even billions of users, have emerged from nowhere in the last decade or two. And even that is just one, small

13. Retrieved from www.bundeskartellamt.de/Pressemitteilungen/ 6November2019 and www.autoritedelaconcurrence.fr/communiquesde-presse/algorithmes-et-concurrence (both consulted on 21 May 2020).

14. Cf. Cremer J., et al. (2019). Competition Policy for the Digital Era. Retrieved from www.ec.europa.eu/competition/publications/reports (consulted on 21 May 2020).

15. Vestager M. (2019, December 9). Defining Markets in a New Age. European Commissioner in Charge of Competition and Digital Transformation, speech. Retrieved from www.ec.europa.eu/commission/ commissioners/2019-2014/vestager (consulted on 21 May 2020).

16. Cf. Retrieved from www.ecp.crai.com/events/the-cra-annual-bursselsconference-2019 (consulted on 21 May 2020). part of a transformation that's affecting every part of our economy. ${ }^{17}$

This 'transformation' may lead - following Mrs. Vestager's approach - to a revamping of the way that competition is regulated and enforced in Europe. Could it also lead to a new approach to competition-related litigation and in particular to a new reliance on such consensual methods of dispute resolution as mediation? Indeed, mediation shares with the new digital economy, a number of characteristics, contrary to traditional dispute resolution through the courts (or arbitration). Mediation, if it is done right, is rapid. As a method, it is designed to arrive at a highly personalised solution, through recourse to the minimum of resources necessary. It is based on the will of the parties, their willpower (and that of the mediator), and their ability to think 'out of the box' towards solutions. It is a method that protects business secrets in an absolute, hermetic way. It favours the maintenance of business relationships, rather than their destruction. And it may be the form of dispute resolution that will correspond to the flux of nem types of conflict, which will flow now in the post-pandemic world.

\section{Conclusion on New Times and New Possibilities for Recourse to Mediation}

In this paper, we have contemplated the recourse to mediation as a dispute resolution mechanism in a discipline - competition law - in which such recourse has been rarely used in the past, and this on a worldwide scale. But now we are in a new world, where companies are obliged by the force of new situations to contemplate new methods.

Indeed, as post-pandemic realities begin to emerge at the time of this writing (mid-2020), it seems clear that businesses, in general, are seizing the occasion to reassess traditional approaches to dispute resolution, and consider new ones, including with regard to competition disputes. In many cases, at the same time that they are fighting to save their businesses, companies have to deal with all kinds of performance and behaviour issues of other companies, particularly in supply chain situations. One of the consequences of the COVID-19 crisis may well be to put a new focus on the relationship between dispute resolution and time. Most likely, it will take a considerable period for courts to absorb the backup consequences of the COVID-19 crisis. In competitionrelated disputes, this may mean prolonged periods of business immobilism, since it would be difficult for parties having previously enjoyed a commercial relationship to continue onwards as before in times of judicial conflict over competition-sensitive legal issues. For this rea-

17. Margrethe Vestager, Speech, 9 December 2019, op cit, footnote 15 
son, judicial resolution of competition-related conflict (that is to say conflict related to market functionings between companies, supply and demand) often means a business divorce as well. An element of prolonged judicial dispute resolution heightens the risk of such business rupture.

In Europe, in the digital economy, a dictum has been forged in business circles: 'The time of the Courts is not the time of business.' It has been said, time and again, and merits to be repeated one last time: in competitionrelated disputes, as in other business disputes, recourse to mediation allows to neutralise the negative effects of time's passage and save business relationships. 